\title{
BODY COMPOSITION AND HASHIMOTO DISEASE
}

\author{
Ewa Malczykl, Joanna Wyka², Agata Malczyk $k^{l}$ \\ ${ }^{1}$ Department of Health Sciences and Physical Education, University of Applied Sciences in Nysa, \\ Armii Krajowej 7, 48-300 Nysa, Poland \\ ${ }^{2}$ Department of Human Nutrition, Wroclaw University of Environmental and Life Sciences, \\ Chełmońskiego 37, 51-630 Wrocław, Poland
}

\begin{abstract}
Background. Body weight or BMI do not provide any information about the content of muscle tissue, water content, body fat and its distribution in the body. Thyroid dysfunction is associated with a change in body weight, but also its composition regardless of physical activity.

Objective. The aim of the study was to compare the body composition of female patients diagnosed with Hashimoto's disease (HD) and the body composition of healthy women who have never been treated before due to thyroid diseases.

Materials and methods. The study involved 47 women diagnosed with Hashimoto disease (HD) and 65 women declaring good health. Body mass and height and body composition analysis using bioelectrical impedance analysis were performed using the TANITA multi-frequency segmental body composition analyzer. Variables having a distribution similar to the normal distribution were analyzed by the analysis of variance (ANOVA), otherwise the Kruskal-Wallis test was used.

Results. Women with Hashimoto disease were characterized by significantly higher values of body weight, and thus BMI index, than healthy women (respectively $73.64 \mathrm{~kg}$ vs. $64.36 \mathrm{~kg}, \mathrm{p}<0.0001 ; 27.65 \mathrm{~kg} / \mathrm{m}^{2} \mathrm{vs} .23 .95 \mathrm{~kg} / \mathrm{m}^{2}, \mathrm{p}<0.001$ ).The problem of excess body fat in the body statistically significantly more often affected women with Hashimoto disease than healthy women $(44.7 \%$ vs. $13.8 \%, \mathrm{p}<0.001)$

Conclusions. The results regarding the weight and composition of the patients treated for thyroid disease indicate the need for further in-depth analyses. Even small abnormalities of the thyroid function in the range of reference values may result in the development of many adverse changes in the body.
\end{abstract}

Keywords: body composition, body mass index (BMI), Hashimoto disease (HD)

\section{STRESZCZENIE}

Wprowadzenie. Masa ciała czy BMI nie dostarczają żadnych informacji o zawartości tkanki mięśniowej, zawartości wody, tkanki tłuszczowej i jej rozmieszczeniu w organizmie. Zaburzenia czynności tarczycy wiążą się ze zmianą masy ciała, ale także jego składu niezależnie od aktywności fizycznej.

Cel. Celem pracy było porównanie składu ciała pacjentek, u których rozpoznano chorobę Hashimoto (HD) oraz składu ciała kobiet zdrowych, które nigdy wcześniej nie były leczone z powodu chorób tarczycy.

Materiały i metody. Badaniem objęto 47 kobiet z rozpoznaną chorobą Hashimoto (HD) oraz 65 kobiet deklarujących dobry stan zdrowia. Analizę masy i wysokości ciała oraz składu ciała z wykorzystaniem analizy impedancji bioelektrycznej przeprowadzono przy użyciu wieloczęstotliwościowego segmentowego analizatora składu ciała firmy TANITA. Zmienne o rozkładzie zbliżonym do normalnego analizowano za pomocą analizy wariancji (ANOVA), w pozostałych przypadkach stosowano test Kruskala-Wallisa.

Wyniki. Kobiety z chorobą Hashimoto charakteryzowały się istotnie wyższymi wartościami masy ciała, a tym samym wskaźnika BMI, niż kobiety zdrowe (odpowiednio 73,64 kg vs. 64,36 kg, p <0,0001; 27,65 kg/m² vs. 23,95 kg/m², $\mathrm{p}<0,001)$. Problem nadmiaru tkanki tłuszczowej w organizmie statystycznie istotnie częściej dotyczył kobiet $\mathrm{z}$ chorobą Hashimoto niż kobiet zdrowych $(44,7 \%$ vs. $13,8 \%, \mathrm{p}<0,001)$.

Wnioski. Uzyskane wyniki dotyczące masy i składu ciała pacjentek leczonych z powodu chorób tarczycy wskazują na potrzebę dalszych pogłębionych analiz. Nawet niewielkie odchylenia funkcji tarczycy w zakresie wartości referencyjnych mogą być przyczyną rozwoju wielu niekorzystnych zmian w organizmie.

Słowa kluczowe: skład ciała, wskaźnik masy ciała (BMI), choroba Hashimoto (HD)

Corresponding author: Joanna Wyka, Department of Human Nutrition, Wroclaw University of Environmental and Life Sciences, Chełmońskiego 37, 51-630 Wrocław, Poland, e-mail: joanna.wyka@upwr.edu.pl 


\section{INTRODUCTION}

Endocrine system diseases are an important health problem in Poland and worldwide [36]. Epidemiological data indicate that more than 300 million people worldwide have thyroid disease, and only $50 \%$ of them are treated [21]. In Poland, endocrinologists estimate that up to $22 \%$ of the population, primarily women, may have thyroid problems $[20,36]$. According to GUS data, in Poland in 2014, thyroid diseases were among the ten most common chronic conditions among women aged 15 years and older $(12.1 \%$ of the female population). In 2014, compared with 2009, the percentage of women declaring the presence of thyroid diseases in the 12 months preceding the survey, increased by $4.2 \%$, and compared with 2004 , by $5.6 \%$. Additionally, it was noted that the prevalence of thyroid gland disease increases with age. Among women aged 60 years and older, the percentage of women declaring to have thyroid disease was $17.2 \%$ $[16,17,18,19]$. One of the most common disorders of the thyroid gland and most often resulting from chronic autoimmune inflammation is hypothyroidism. It affects approximately $4-10 \%$ of the population [12, 36]. Thyroid diseases are characterized by abnormal levels of hormones produced by the thyroid gland (T3 and T4) and thyroid-stimulating pituitary hormone (TSH), resulting in many disorders of physiological body functions. Thyroid hormone deficiency can cause kidney dysfunction, glucose intolerance, hyperlipidemia, and decreased phosphate levels [1]. Patients with thyroid dysfunction may also be more likely to develop insulin resistance, type 2 diabetes and cardiovascular disease [13, 15, 37]. Some researchers even suggest that thyroid function tests should be considered in the diagnosis of metabolic disorders [1]. Thyroid dysfunction (hypothyroidism) alters appetite and makes it difficult to maintain normal body weight and composition (body fat). Thus, it can be concluded that thyroid hormones (T3, T4) are potent modulators of thermogenesis, and their deficiency can potentially contribute to the development of obesity $[23,32,34]$. There is clinical evidence to suggest that even mild thyroid dysfunction in the form of subclinical hypothyroidism can lead to significant changes in body weight and thus may be a risk factor for overweight and obesity. However, the relationship between hypothyroidism and obesity is still under debate $[8,34]$.

Most studies on the relationship between thyroid dysfunction and body weight change are based on the analysis of simple indicators, such as body weight or BMI [2, 10, 26, 27]. These indicators do not provide any information about the content of muscle tissue, water content, body fat and its distribution in the body. As reported by Sanyala and Raychaudhuri [34], thyroid dysfunction is associated with a change in body weight, but also its composition regardless of physical activity. Adipose tissue is not only for energy storage, but is above all an active internal endocrine organ. It contains many types of cells, such as fat cells, immune cells and fibroblasts. It consists of brown and white adipose tissue. Brown adipose tissue (BAT) plays a key role in the production of heat by thermogenesis. The prevalence of BAT decreases with increasing body weight, and therefore active BAT in adults plays an important role in maintaining normal body mass, i.e. prevents obesity and also insulin resistance [6].

In turn, white adipose tissue is responsible for storing energy in the form of triacylglycerols in situations of a positive energy balance and release of free fatty acids during a shortage of energy, but above all it is the main endocrine organ. Its products, including adiponectin, leptin, and resistin, are involved in many metabolic changes. Adiponectin is particularly effective in the transformation of glucose and fatty acids in the liver and muscles, sensitizes the tissues to insulin, and also has anti-inflammatory and antiatherosclerotic effects. In people with excessive body fat, the adipokine secretion profile undergoes specific changes. The production process of adiponectin is slowed down, resulting in a higher incidence of metabolic diseases and diabetes. The concentration of leptin increases in proportion to the amount of fat in the body. Leptin is a hormone that improves insulin sensitivity and modulates the function of pancreatic cells, and also regulates energy consumption and body weight. However, at an excessively high concentration in obese people it can cause the opposite effect resistance to lectin. Deficiency, but also resistance to leptin, intensifies lipogenesis, thereby promoting deposition of adipose tissue [3, 6, 15]. In a study conducted by Marzullo et al. [29], it was suggested that excess leptin in obesity is a risk factor for autoimmune thyroid disease, thus indicating a relationship between the main cause of acquired thyroid insufficiency and obesity. Thyroid hormone deficiency also results in impaired physiological functions affecting adipose tissue metabolism through decreased lipoprotein lipase (LPL) activity. This was confirmed in a study by Chen et al [6 ], who showed a significant increase in serum triacylglycerols, cholesterol, and LDL lipoprotein fractions in hypothyroid patients. These researchers also [6] determined elevated leptin levels in hypothyroid subjects who had a high BMI. In turn, Ouchi et al. [31] found that thyroid-stimulating hormone (TSH) had a direct effect on the secretion of leptin. Leptin, stimulates the release of thyrotropin, the hypothalamic hormone and increases the conversion of thyroxine (T4) to triiodothyronine (T3) [26]. Such a relationship was also proven in studies by Betra et al. [3] and Roef et al. [33] conducted among young with 
euthyroid and obese men. In addition, excess adipose tissue, especially visceral, leads to the development of chronic subclinical inflammation. During lipolysis, large amounts of free fatty acids are released into the circulation, which activate the immune system, thus promoting inflammatory and atherosclerotic processes [35].

The aim of the study was to compare the body composition of female patients diagnosed with Hashimoto's disease (HD) and the body composition of healthy women who have never been treated before due to thyroid diseases.

\section{MATERIAL AND METHODS}

The research was conducted among 112 women aged 20-65 living in the south-western part of Poland (Opolskie and Dolnośląskie Voivodships). The criteria for inclusion in the study were: age over 18 years, gender: women, declared good health or with Hashimoto disease (diagnosed by a doctor and lasting for 3 to 5 years) consent to participate in the study. The exclusion criteria were: below 18 years old, gender: men, implanted pacemaker, pregnancy, menstruation, atherosclerosis, diabetes, hypertension, overactive thyroid gland, stroke, liver disease and systematic use of diuretics. The study involved 47 women diagnosed with $\mathrm{HD}$ and 65 women declaring good health and never before treated for thyroid disease. Before participating in the study, the participants were asked to complete a questionnaire containing questions regarding their age, sex, education, type of family, place of residence, physical activity and financial status. Healthy women were compared with women with Hashimoto's disease according to age distribution ( $\leq 30$ years, 31-40 years, 41-50 years, 51-65 years), education (primary, secondary, high), type of family (lonely, married, family with children), place of living (urban, rural), physical activity (lack, moderate activity, over $30 \mathrm{~min} /$ day), financial status (below 1000 PLN, 1000-2000 PLN, 2001-3000 PLN, 3001-4000 PLN, above 4000 PLN).

\section{Body composition analysis}

The research was carried out in the morning hours. Body height measurement was done in an upright position, without footwear, using an anthropometer with an accuracy of $0.1 \mathrm{~cm}$. However, body mass measurement (with an accuracy of $0.1 \mathrm{~kg}$ ) and body composition analysis using bioelectrical impedance analysis (BIA) were performed using the MC 780 SMA TANITA multi frequency segmental body composition analyzer. Analysis of body composition allowed determination of mass and percentage of adipose tissue, mass of lean tissue, muscle mass, total water content in the body, mass of intracellular and extracellular water, ratio of extracellular water to total water content and bone mass. On the basis of the obtained measurements, the body mass index (BMI) and the index of visceral tissue were also determined. To assess the nutritional status on the basis of the BMI, WHO classification criteria were adopted [30]. Normal values for body fat were adopted in accordance with WHO/NIH recommendations [5]. Women containing more than $35 \%$ of adipose tissue were classified as obese. The reference values for the indicator of visceral tissue and water content in the body were adopted as recommended by the manufacturer of the body composition analyzer TANITA, respectively $0-12$ and $45 \%-60 \%$ [ 25].

\section{Statistical analysis}

The hypothesis on the normal distribution of the analyzed variables was verified using the ShapiroWilk test. Variables having a distribution similar to the normal distribution were analyzed by the analysis of variance (ANOVA), otherwise the Kruskal-Wallis test was used. The mean value,standard deviation, median, minimum and maximum values of all analyzed variables were calculated for the entire examined group. In order to confirm the lack of difference in the sociodemographic evaluation between the examined women who were diagnosed with HD and healthy women, the Chi-squared independence test with the Yates correction was carried out. Thistest was also used to verify selected parameters of body composition (content of adipose tissue, index of visceral tissue, water content in the body) and BMI depending on the health of the examined women. Statistically significant differences were adopted at $p$ $<0.05$. Statistical analyses were carried out using the Statistica v.13.1 software.

\section{RESULTS}

\section{General characteristics}

The studied groups of women were not different in terms of age, education, type of family, place of residence, physical activity or financial status $(\mathrm{p}>0.05)$. The average age of healthy women (control sample) was 46 years and of patients 48 years. The most numerous group was that of women aged 41 to $50(31.3 \%)$, and then aged $31-40$ (28.6\%). The fewest (13.3\%) participants of the study were aged between 19 and 30 years (Table 1). Over $72 \%$ of the surveyed women had a university degree, and about $2 \%$ were professional. Other women declared secondary education. The women who took part in the study $(65.2 \%)$ lived with children or in multigenerational families. Every fifth respondent lived in a married or informal relationship $(19.6 \%)$. Among the respondents, $15.2 \%$ were alone. Participants in the study lived in urban areas (56.2\%) 
Table 1. Socio-economic characteristics of the surveyed women

\begin{tabular}{|c|c|c|c|c|}
\hline \multirow{2}{*}{\multicolumn{2}{|c|}{ Parameter }} & $\begin{array}{c}\text { All women } \\
{[\%]}\end{array}$ & $\begin{array}{c}\text { Healthy women } \\
{[\%]}\end{array}$ & $\begin{array}{c}\text { Women with HD } \\
{[\%]}\end{array}$ \\
\hline & & 100.0 & 58.0 & 42.0 \\
\hline \multirow{4}{*}{ Age [years] } & $\leq 30$ & 13.3 & 18.5 & 6.4 \\
\hline & $31-40$ & 28.6 & 27.7 & 29.8 \\
\hline & $41-50$ & 31.3 & 24.6 & 40.4 \\
\hline & $51-65$ & 26.8 & 29.2 & 23.4 \\
\hline \multirow{3}{*}{ Education } & primary & 1.8 & 3.1 & 0.0 \\
\hline & secondary & 25.8 & 30.8 & 19.1 \\
\hline & high & 72.4 & 66.1 & 80.9 \\
\hline \multirow{3}{*}{ Type of family } & lonely & 15.2 & 16.9 & 12.8 \\
\hline & married & 19.6 & 18.5 & 21.3 \\
\hline & family with children & 65.2 & 64,6 & 65.9 \\
\hline \multirow{2}{*}{ Place of living } & urban area & 56.2 & 63.1 & 46.8 \\
\hline & rural area & 43.8 & 36.9 & 53.2 \\
\hline \multirow{3}{*}{ Physical activity } & lack & 18.8 & 18.5 & 19.1 \\
\hline & moderate activity & 52.7 & 47.7 & 59.6 \\
\hline & over $30 \mathrm{~min} /$ day & 28.5 & 33.8 & 21.3 \\
\hline \multirow{5}{*}{ Financial status } & $<1000$ PLN & 5.4 & 9.2 & 0.0 \\
\hline & 1000-2000 PLN & 55.3 & 58.5 & 51.1 \\
\hline & 2001-3000 PLN & 23.2 & 23.1 & 23.4 \\
\hline & 3001-4000 PLN & 11.6 & 7.7 & 17.0 \\
\hline & $>4000$ PLN & 4.5 & 1.5 & 8.5 \\
\hline
\end{tabular}

$p$-value - test $\mathrm{Chi}^{\wedge} 2$ with Yates, $\mathrm{p}<0.05,4 \mathrm{PLN}=1$ EURO

as well as rural areas (43.8\%). Over half (52.7\%) of women declared moderate physical activity, and every fifth woman admitted to physical inactivity. Most women earned between 1000 and 2000 zlotys (55.3\%), and then from 2001 to 3000 zlotys (23.2\%). Statistical analysis did not show differences between healthy women (control sample) and women with HD in terms of age, education, type of family, place of residence, physical activity and financial status (Table 1). Women diagnosed with HD reported that they had suffered from the disease from an average of 3 to 5 years and were under constant endocrine control.

\section{Analysis of selected anthropometric parameters}

Taking into account the BMI, it was found that almost half $(48.2 \%)$ of the subjects were characterized by normal body weight (Table 2). They were significantly more often healthy women than women with diagnosed hypothyroidism $(66.2 \%$ vs. $23.4 \%$, $\mathrm{p}<0.0001)$. On the other hand, anomalous body mass was diagnosed more often $(76.6 \%$ vs. $33.8 \%$, $\mathrm{p}<0.0001)$. Regardless of the health condition, the examined women were overweight most often. Obesity was found in every fifth participant of the study. Body fat deficiency was observed in one woman $(1.7 \%)$ (Table 2). According to the adopted WHO/NIH criteria for the content of adipose tissue in the female body, it was found that $26.8 \%$ of the respondents were characterized by its improper content. The problemof excess body fat in the body statistically significantly more often affected women with HD than healthy women $(44.7 \%$ vs. $13.8 \%, p<0.001)$. The majority $(98.2 \%)$ of the study participants were characterized by the correct value of the visceral tissue index. The abnormal water content in the body was demonstrated in $23.2 \%$ of women. Statistically significantly more often they were womenwith HD than healthy subjects $(36.2 \%$ vs. $13.8 \%, p<0.01)$. The correct values of this parameter were found in $76.8 \%$ of subjects, and in this group healthy women dominated $(86.1 \%$ vs. $63.8 \%$, $\mathrm{p}<0.01$ ) (Table 2).

The results of the body composition analysis are presented in Table 3. Women who were diagnosed with HD were characterized by significantly higher values of body weight, and thus BMI index, than healthy women (respectively $73.64 \mathrm{~kg}$ vs. $64.36 \mathrm{~kg}, \mathrm{p}<0.0001$; $27.65 \mathrm{~kg} / \mathrm{m}^{2}$ vs. $\left.23.95 \mathrm{~kg} / \mathrm{m}^{2}, \mathrm{p}<0.001\right)$. Also the body composition of the studied women with HD differed statistically significantly from healthy women. In patients, significantly higher content of adipose tissue (33.62\% vs. $26.77 \%, \mathrm{p}<0.0001)$, fat free mass $(48.45$ kg vs. $46.46 \mathrm{~kg}, \mathrm{p}=0.0232)$, muscle mass $(46.04 \mathrm{~kg}$ 
Table 2. Analysis of selected anthropometric parameters in the group of healthy and HD women

\begin{tabular}{|c|c|c|c|c|}
\hline \multicolumn{2}{|c|}{ Parameter } & $\begin{array}{c}\text { All women } \\
{[\%]} \\
\end{array}$ & $\begin{array}{c}\text { Healthy women } \\
{[\%]}\end{array}$ & $\begin{array}{c}\text { Women with HD } \\
{[\%]}\end{array}$ \\
\hline \multirow{6}{*}{ BMI $\left[\mathrm{kg} / \mathrm{m}^{2}\right]$} & & & & \\
\hline & normal & 48.2 & 66.2 & 23.4 \\
\hline & unnormal including: & 51.8 & 33.8 & 76.6 \\
\hline & underweight & 1.7 & 4.6 & 0.0 \\
\hline & overweight & 79.3 & 72.7 & 83.3 \\
\hline & obesity & 19.0 & 22.7 & 16.7 \\
\hline \multirow{2}{*}{ Adipose tissue [\%] } & $<35$ & 73.2 & 86.2 & 55.3 \\
\hline & $>35$ & 26.8 & 13.8 & 44.7 \\
\hline \multirow{2}{*}{ Visceral tissue index } & $1-12$ & 98.2 & 100.0 & 95.7 \\
\hline & $13-59$ & 1.8 & 0.0 & 4.3 \\
\hline \multirow{2}{*}{ TBW $[\%]$} & normal & 76.8 & 86.1 & 63.8 \\
\hline & unnormal & 23.2 & 13.8 & 36.2 \\
\hline
\end{tabular}

p-value - test $\mathrm{Chi}^{\wedge} 2$ with Yates, $\mathrm{p}<0.05$

Table 3. Descriptive statistics of anthropometric parameters in the group of healthy women with HD

\begin{tabular}{|c|c|c|c|}
\hline \multirow[b]{2}{*}{ Parameter } & Healthy women & Women with HD & \multirow[b]{2}{*}{ p-value } \\
\hline & $\begin{array}{c}\text { Mean } \pm \text { SD; } \\
\text { Median; min-max }\end{array}$ & $\begin{array}{c}\text { Mean } \pm \text { SD; } \\
\text { Median; min-max }\end{array}$ & \\
\hline Body mass [kg] & $\begin{array}{c}64.36 \pm 12.37 \\
61.85 ; 47.8-118.5\end{array}$ & $\begin{array}{c}73.64 \pm 11.66 \\
73.60 ; 52.9-102.5\end{array}$ & $<0.0001$ \\
\hline BMI $\left[\mathrm{kg} / \mathrm{m}^{2}\right]$ & $\begin{array}{c}23.95 \pm 4.15 \\
22.90 ; 18.3-38.3\end{array}$ & $\begin{array}{c}27.65 \pm 4.56 \\
27.00 ; 20.2-41.6\end{array}$ & $<0.001$ \\
\hline Adipose tissue [\%] & $\begin{array}{c}26.77 \pm 6.65 \\
26.20 ; 12.8-42.3\end{array}$ & $\begin{array}{c}33.62 \pm 6.16 \\
34.10 ; 16.3-41.9\end{array}$ & $<0.0001$ \\
\hline FM $[\mathrm{kg}]$ & $\begin{array}{c}17.80 \pm 7.76 \\
16.30 ; 6.6-48.1 \\
\end{array}$ & $\begin{array}{c}25.27 \pm 7.43 \\
24.80 ; 8.6-42.9 \\
\end{array}$ & $<0.0001$ \\
\hline Visceral tissue index & $\begin{array}{c}4.18 \pm 2.64 \\
4.00 ; 1.0-11.0\end{array}$ & $\begin{array}{c}7.12 \pm 2.80 \\
7.00 ; 1.0-13.0\end{array}$ & $<0.0001$ \\
\hline FFM [kg] & $\begin{array}{c}46.46 \pm 5.77 \\
45.00 ; 37.6-60.4\end{array}$ & $\begin{array}{c}48.45 \pm 4.48 \\
48.00 ; 43.0-61.4\end{array}$ & 0.0232 \\
\hline Muscles mass [kg] & $\begin{array}{c}44.10 \pm 5.48 \\
42.70 ; 35.7-56.9 \\
\end{array}$ & $\begin{array}{c}46.04 \pm 4.28 \\
45.80 ; 40.8-58.3\end{array}$ & 0.0123 \\
\hline Bone mass [kg] & $\begin{array}{c}2.36 \pm 0.29 \\
2.30 ; 1.9-3.5\end{array}$ & $\begin{array}{c}2.47 \pm 0.23 \\
2.40 ; 2.2-3.1\end{array}$ & 0.0275 \\
\hline TBW $[\%]$ & $\begin{array}{c}52.29 \pm 4.90 \\
52.80 ; 41.0-62.1 \\
\end{array}$ & $\begin{array}{c}47.24 \pm 4.57 \\
46.64 ; 41.4-60.5\end{array}$ & $<0.0001$ \\
\hline TBW $[\mathrm{kg}]$ & $\begin{array}{c}33.16 \pm 4.11 \\
32.1 ; 26.9-50.4 \\
\end{array}$ & $\begin{array}{c}34.47 \pm 3.23 \\
34.10 ; 30.5-43.7\end{array}$ & 0.0370 \\
\hline $\mathrm{ECW}[\mathrm{kg}]$ & $\begin{array}{c}14.22 \pm 1.96 \\
13.90 ; 11.2-22.8 \\
\end{array}$ & $\begin{array}{c}15.38 \pm 1.54 \\
15.20 ; 12.7-19.5 \\
\end{array}$ & $<0.001$ \\
\hline ICW $[\mathrm{kg}]$ & $\begin{array}{c}18.95 \pm 2.34 \\
18.80 ; 15.7-28.7\end{array}$ & $\begin{array}{c}19.07 \pm 1.94 \\
18.70 ; 16.0-24.4\end{array}$ & 0.6491 \\
\hline ECW / TBW [\%] & $\begin{array}{c}42.84 \pm 1.82 \\
42.40 ; 39.3-46.6\end{array}$ & $\begin{array}{c}44.66 \pm 1.95 \\
44.88 ; 39.7-47.6\end{array}$ & $<0.0001$ \\
\hline
\end{tabular}

p-value - ANOVA and Kruskal-Wallis test $\mathrm{p}<0.05$ 
vs. $44.10 \mathrm{~kg}, \mathrm{p}=0.0123)$ and bone mass $(2.47 \mathrm{~kg}$ vs. $2.36 \mathrm{~kg}, \mathrm{p}=0.0275$ ) were found (Table 3). Statistical analysis also proved that in women with HD the fat tissue distribution (assessed as visceral tissue index) was dominant, in contrast to healthy women (7.12 vs. $4.18, \mathrm{p}<0.0001)$. The health status of the studied women also had a significant effect on the total body water (TBW\%), which was statistically significant higher in healthy women than in patients with HD $(52.29 \%$ vs. $47.24 \%, \mathrm{p}<0.0001)$. At the same time, the female patients were characterized by a significantly higher content of extracellular water $(\mathrm{ECW} \mathrm{kg}$ ) than healthy women $(15.3 \mathrm{~kg}$ vs. $14.22 \mathrm{~kg}, \mathrm{p}<0.001)$. The ECW/TBW ratio was also significantly higher in patients with HD than in healthy women (44.66 vs. $42.84, \mathrm{p}<0.0001$ ).

\section{DISCUSSION}

In the present study, an abnormal ratio of body weight to height was found in $76.6 \%$ of women diagnosed with $\mathrm{HD}$, overweight in $83.3 \%$ and obesity in $16.7 \%$ of women. In the control group (healthy women) overweight and obesity were found in $72.7 \%$ and $22.7 \%$ of the subjects respectively. Lee et al. [24] investigating 101 patients with primary hypothyroidism, achieved a reduction in TSH level from $18.3 \mathrm{mIU} / \mathrm{L}$ to $2.3 \mathrm{mIU} / \mathrm{L}$ after a five-month thyroxine treatment period $(\mathrm{p}<0.0001)$. There were no statistically significant changes in body weight (from $79.6 \mathrm{~kg}$ to $78.9 \mathrm{~kg}, \mathrm{p}=0.30$ ) or BMI (from $29.3 \mathrm{~kg} / \mathrm{m} 2$ to $28.8 \mathrm{~kg} / \mathrm{m} 2, \mathrm{p}=0.25$ ). Bjergved et al. [4] in studies conducted among adults over 11 years indicated the existence of a relationship between body weight and serum TSH concentration. Other researchers [7,22] suggested that the observed weight loss obtained after starting treatment for hypothyroidism results from the loss of previously accumulated water in the body. Karmisholt et al. [22] justified their theory by conducting research among 12 newly diagnosed patients with hypothyroidism whose mean TSH value was $102 \mathrm{mIU} / \mathrm{L}$. The conducted studies showed changes in weight and body composition after one year from taking the therapy. There was a statistically significant decrease in body weight (on average by $4.3 \mathrm{~kg}$ ). However, there was no significant change in body fat content. In this study, women with HD not only had significantly BMI, but also statistically significantly higher fat content in the body compared to healthy women (control sample). Our research as well as cited authors confirmed earlier analyses carried out by Miyakaw et al. [28]. They reported that women with HD were characterized by higher content of adipose tissue compared to people with normal thyroid hormone levels. In our research, the excess of centrally located fatty tissue did not exceed the reference values, although the determined index of visceral tissue was statistically significantly higher in patients than in healthy women. De Pergola et al. [11] drew the conclusion, based on studies carried out among 201 women with HD and overweight or obesity, that progressive central fat accumulation is associated with increased levels of TSH, independent of insulin sensitivity, metabolic parameters and blood pressure. In addition, they suggested that the control of TSH secretion by free thyroid hormones is probably impaired in obesity. Considering the above, it can be suggested that accumulated fat during subclinical or clinical hypothyroidism may further disturb metabolic functions (decreased adiponectin concentration, increased leptin secretion) and consequently negatively affect the body, predisposing to obesity and increasing the risk of other metabolic diseases.

A recently published study by Glymph and Gosmanov [14] suggested differentiation of the T4 dose for obese and non-obese women with HD after complete thyroidectomy. In addition, they show that a better predictor to help determine the optimal $\mathrm{T} 4$ dose for obese women after complete removal of the thyroid gland is ideal body weight than total body water (TBW). However, the authors of the study claim that the use of ideal body weight as a substitute measure of fat free mass can potentially lead to underestimation or overestimation of body weight, and cause differences in the calculation of $\mathrm{T} 4$ per $\mathrm{kg}$ of ideal body weight. Effectively, this problem can be eliminated by introducing patient body analysis in the treatment standard.

Our own studies also included analysis of total body water as well as extracellular (ECW) content in the body. It was observed that every fifth woman tested had abnormal water content (TBW) in the body. Statistically significantly more often they were people with $\mathrm{HD}(36.2 \%$ vs. $13.8 \%$; $<<0,01$, table 2$)$. In the study by Miyakawa et al. [28], lower water content (TBW) was found in the HD group compared to the control group. In the study by Lorenzo et al. [9], analyzing the effects of subclinical hypothyroidism on body composition, 31 women considered BIA analysis as an important tool for assessing body composition and body fluid distribution in subclinical hypothyroidism.

\section{CONCLUSION}

In conclusion, our own research and other researchers regarding the weight and composition of the patients treated for thyroid disease indicate the need for further in-depth analyses. Even small abnormalities of the thyroid function in the range of reference values may result in the development of many adverse changes in the body. The diagnosis of thyroid dysfunction including HD diseases should be extended 
by the body composition, especially body fat, to minimize the risk of other diseases. Proper assessment of anthropometric parameters may determine the correct dose of drugs in pharmacotherapy in thyroid diseases.

\section{Conflict of interest}

The Authors declare no conflict of interest.

\section{REFERENCES}

1. Abdel-Gayoum A.A.: Dyslipidemia and serum mineral profiles in patients with thyroid disorders. Saudi Med J 2014;35(12):1469-1476.

2. Asvold B.O., Bjoro T., Vatten L.J.: Association of serum TSH with high body mass differsbetween smokers and never-smokers. J Clin Endocrinol Metab 2009;94:50235027.

3. Betry C., Challan-Belval M.A., Bernard A., Charrié A., Drai J., Laville M., Thivolet $C$., Disse E.: Increased TSH in obesity: Evidence for a BMI-independent association with leptin. Diabetes Metab 2015; 41: 248-251. DOI: http://dx.doi.org/10.1016/j.diabet.2014.11.009.

4. Bjergved L., Jørgensen T., Perrild H., Laurberg P., Krejbjerg A., Ovesen L., Rasmussen L.B., Knudsen N.: Thyroid Function and Body Weight: A CommunityBased LongitudinalStudy. PLoS ONE 2014;9(4):e93515.

5. Burkhauser R.H., Cawley J.: Beyond BMI: The value of more accurate measures of fatnessand obesity in social science research. J Health Econom 2008;27:519-529.

6. Chen $X$., $W u X$., Wu R., Sun $X$., Yang B., Wang $Y$., $X u Y .:$ Changes in profile of lipids and adipokines in patients with newly diagnosed hypothyroidism and hyperthyroidism. Sci Rep2016; 6: 26174.

7. Dale J., Daykin J., Holder R., Sheppard M.C., Franklyn $J$.A.: Weight gain followingtreatment of hyperthyroidism. Clin Endocrinol (Oxf). 2001;55(2):233-239.

8. Danforth E., Horton E.S., O'Connell M., Sims E.A., Burger A.G., Ingbar S.H., et al. Dietary-induced alterations in thyroid hormone metabolism during over nutrition. J Clin Invest 1979;64:1336-47.

9. De Lorenzo A., Andreoli A., Fusco A., Magnani A., D'Orazio $N$., Bertoli A.: Effect of subclinical hypothyroidism on body fluid compartments. Horm Metab Res 2000;32(9):359-363.

10. De Moura Souza A., Sichieri R.: Association between serum TSH concentration within thenormal range and adiposity. Eur J Endocrinol 2011;165:11-15.

11. De Pergola G., Ciampolillo A., Paolotti S., Trerotoli $P$., Giorgino R.: Free triiodothyronine and thyroid stimulating hormone are directly associated with waist circumference, independently of insulin resistance, metabolic parameters and blood pressure in overweight and obese women. Clin Endocrinol (Oxf). 2007;67:265269.

12. Gawrychowski J., Jastrząb B.: Choroby tarczycy i przytarczyc. Diagnostyka i leczenie, Wydawnictwo Medipage, Warszawa 2014.
13. Gierach M., Gierach J., Junik R.: Insulin resistance and thyroid disorders. Endokrynol Pol 2014;65(1):70-76. DOI: 10.5603/EP.2014.0010.

14. Glymph K., Gosmanov A.R.: Levothyroxine replacement in obese hypothyroid femalesafter total thyroidectomy. Endocr Pract 2016;22:22-29.

15. Gronich N., Deftereos S.N., Lavi I., Persidis A.S., Abernethy D.R., Rennert G.: Hypothyroidism is a risk factor for new-onset diabetes: a cohort study. Diabetes Care 2015;38:1657-1664. DOI: 10.2337/dc14-2515.

16. GUS. Ludność w wieku 60 lat i więcej. Struktura demograficzna i zdrowie. GUS Warszawa 2016b: 15.

17. GUS. Stan zdrowia ludności Polski w 2004 roku. GUS Warszawa 2006:100-121.

18. GUS. Stan zdrowia ludności Polski w 2014 roku. GUS Warszawa 2016a:66-67.

19. GUS. Zdrowie kobiet w Polsce w latach 2004-2009. GUS Kraków 2012:36-37.

20. https://www.medicover.pl/files/public/uploads/ Choroby_tarczycy.pdf

21. http://poland.merck.de/pl/0140_dlapacjenta/06/ tarczyca.html

22. Karmisholt J., Andersen S., Laurberg P.: Weight loss after therapy of hypothyroidism is mainly caused by excretion of excess body water associated with myxoedema. J Clin Endocrinol Metab 2011;96:E99E103.

23. Krotkiewski M.: Thyroid hormones in the pathogenesis and treatment of obesity. Eur J Pharmacol 2002;440:8598.

24. Lee S.Y., Braverman L.E., Pearce E.N.: Changes in body weight after treatment of primaryhypothyroidism with levothyroxine. Endocr Pract 2014;20:1122-1128.

25. Lemos T., Gallagher D.: Current body composition measurement techniques. Curr Opin Endocrinol Diabetes Obes 2017;24(5):310-314.

26. Makepeace A.E., Bremner A.P., O'Leary P., Leedman P.J., Feddema P., Michelangeli V., Walsh J.P.: Significant inverse relationship between serum free T4 concentration and body mass index in euthyroid subjects: differences between smokers and nonsmokers. Clin Endocrinol 2008;69:648-652.

27. Manji N., Boelaert K., Sheppard M.C., Holder R.L., Gough S.C., Franklyn J.A.: Lack of association between serum TSH or free T4 and body mass index in euthyroid subjects. ClinEndocrinol 2006;64:125-128.

28. Miyakawa M., Tsushima T., Murakami H., Isozaki O., Takano K.: Serum leptin levels and bioelectrical impedance assessment of body composition in patients with Graves' disease and hypothyroidism. Endocr. J 1999;46(5):665-673.

29. Marzullo P., Minocci A., Tagliaferri M.A., Guzzaloni G., Di Blasio A., De Medici C., Aimaretti G., Liuzzi $A$.: Investigations of thyroid hormones and antibodies in obesity: leptin levels are associated with thyroid autoimmunity independent of bioanthropometric, hormonal and weight-related determinants. J Clin Endocrinol Metab 2010;95(8):3965- 3972.

30. Nuttall F.Q.: Body Mass Index. Obesity, BMI, and health: A critical review. Nutr Today. 2015;50(3):117128. 
31. Ouchi N., Parker J.L., Lugus J.J., Walsh K.: Adipokines $\mathrm{i}$ inflammation and metabolicdisease. Nat Rev Immunol 2011;11:85-97.

32. Reinehr T:: Obesity and thyroid function. Mol Cell Endocrinol. 2010;316(2):165-71. DOI: 10.1016/j. mce.2009.06.005

33. Roef G, Lapauw B, Goemaere S, Zmierczak $H G$, Toye K, Kaufman JM, Taes Y.: Body composition and metabolic parameters are associated with variation in thyroid hormone levels among euthyroid young men. Eur J Endocrinol 2012;167:719-726.

34. Sanyal D., Raychaudhuri M.: Hypothyroidism and obesity: An intriguing link. Indian J Endocr Metab 2016;20:554-557. doi: 10.4103/2230-8210.183454.

35. Siemińska L.: Adipose tissue. Pathophysiology, distribution, sex differences and the role in inflammation and cancerogenesis. Endokrynol Pol 2007;58(4): 330-342.

36. Szwajkosz K., Wawryniuk A., Sawicka K., Łuczyk R., Tomaszewski A.: Hypothyroidism being caused by chronic autoimmune inflammation of the thyroid gland. Journal of Education, Health and Sport. 2017;7(5):41-54. DOI:http://dx.doi.org/10.5281/zenodo.569840;

37. Taylor P.N., Razvi S., Pearce S.H., Dayan C.M.: A review of the clinical consequences of variation in thyroid function within the reference range. J Clin Endocrinol Metab 2013; 98:3562-3571.

Received: 10.06 .2021

Accepted: 30.08.2021

Published online first: 22.09.2021 